\title{
砂地盤及び粘土地盤に支持された直接基礎構造物の浮き上がり挙動 UPLIFT BEHAVIOUR OF SPREAD FOUNDATION STRUCTURES ON SAND AND CLAY DEPOSITS
}

\author{
今村 晃 ${ }^{* 1}$, 橋本尚 之*2, 鈴木 康 嗣*3, 安達直 ${ }^{* 4}$, 酒向 裕司*5 \\ Akira IMAMURA, Takayuki HASHIMOTO, Yasutsugu SUZUKI, \\ Naohito ADACHI and Yuji SAKO
}

\begin{abstract}
It is important to accurately estimate the effects of the building basemat uplift and structural response for strong earthquake motions in seismic design of nuclear power plant buildings. In this paper, dynamic centrifuge tests were performed using rigid structure on sand and clay deposits to investigate the difference of structure response due to difference in the bearing stratum, and effect of adhesion between basemat and clay deposit. It was shown that (1) the adhesion was effective in suppressing uplift; (2) the building on sand and clay deposit showed different earthquake response; (3) the JEAC equation for ground contact ratio gave a safe side estimation.
\end{abstract}

Keywords: Uplift, Slip, Stread foundation, Centrifuge model test, Shaking table test, Earth pressure 浮き上がり，滑り，直接基礎，遠心模型実験，振動台実験，土圧

\section{1.はじめに}

原子力施設の耐震設計に稀いて，地震時の転倒モーメントによっ て構造物底面が地盤から部分的に浮き上がる現象は，構造物自体の 耐力や構造安全性に関わる問題だけではなく，構造物内に設置され る機器類の応答に影響孛及ぼすため, 非常に重要な問題である。 1970年代から各研究機関で様々な解析的検討 ${ }^{1)-18)}$ が行われると共 に, 実験的検討 $\left.{ }^{47}, 7\right)-\varepsilon ， 11 ， 12 ， 18$ が行われてきた。解析的, 実験的な各 種検討から，構造物浮き上がり時には転倒モーメントが一定值以上 に増えないため, 水平加速度に頭打ちが生じると共に，上下加速度 が誘発されるといら答特性が明らかになっている。また,これら の知見を採り入れた原子力施設の耐震設計法 ${ }^{1 \varepsilon}$ が実設計に用いら れている。

一方, 橋梁の基礎 2 や鉄道構造物の基礎 20 などの土木構造物や, 一

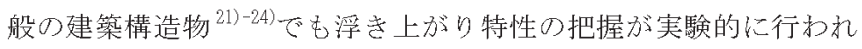
てきた。また，阪神大震陊に和ける建物被害の分析から，建物の浮き

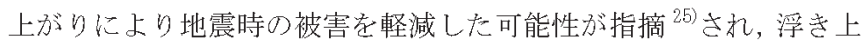
がりを利用した制振構造の研究 26 も行われている。

上記の実験的な研究では，地盤に弾性体のシリコンゴム4),8),9),13) やウレタンゴム7), ソイルセメント ${ }^{18)}$, 弹性バネ21), 剛体 ${ }^{28), 24) な と ゙, ~}$ 実際の地盤上は異なる材料学用いた研究が多く，実地盤で行われた 実験 ${ }^{11)}$ を除けば，実際の地盤材料を用いた実験は原子力施設を対象 としていない事例 ${ }^{20), 22)}$ しか見当たらない。また,これらの実験に用
いられた地盤材料は，いずれも地盤作製が容易な砂である。砂地盤 の強度や剛性は上載圧の影響老強く受けるため, 模型実験用に通常 作製さ杞る砂地盤洼，地表のせん断剛性や強度が非常に小さくなっ ていると考えられるが，原子力施設の支持地盤怡强度・剛性共に非 常に大きな地盤であるため，上載圧依存性が異なっている。また，原 子力施設の支持地盤になっている泥岩の上うな極端に圧密された 粘性土地盤では，乾燥砂にはほとんど無い粘着力に起因して構造物 底面上地盤間に付着力が働き，構造物の浮き上がり特性に影響を与 えるもの上考えられる。しかし，実地盤で行われた実験 ${ }^{11}$ を除けば， 粘土地盤上で行われた浮き上がり実験は見当たらず，砂地盤上粘土 地盤に支持された構造物の浮き上唯り挙動の違いや，構造物底面付 着力の影響に関しては不明な点が多い。

そこで，構造物の浮き上がり挙動に及ぼ寸支持地盤材料の違い上 構造物底面に生じる付着力の有無の影響孛把握するため, 乾燥砂地 盤和上び飽和粘土地盤上に設置した直接基礎構造物の遠心模型に よる振動台実験䘮行った。これらの実験結果から, 構造物の浮き上 がり举動の基本的な特徽や，支持地盤材料の違い之付着力の有無の 影響を検討した。本論で用いた支持地盤恃，原子力施設の支持地盤 である泥岩ほよ゙強度・剛性が大きな地盤ではないが，基本的特性の 把握を目的に，砂地盤上粘土地盤を用いた。な杼，実際の構造物には 埋め込みがある場合が多いが，埋め込み効果に関しては次報以降に 報告する予定である。

\footnotetext{
*1 東京電力(株)技術開発センター耐震技術グループ スペシャリスト・博士 (工学)

*2 東京電力(侏)原子力設備管理部原子力耐震技術センター 地震グループ 修士(工学)

*3 (制)小堀鐸二研究所プロジェクト部 部長・博士 (工学)

*4 (株)小堀鐸二研究所プロジェクト部 課長・博士 (工学)

*5 (株)小堀鐸二研究所構造部 担当部長·博士 (工学)
}

\section{SP, Seismic Design Group, R \& D Center, Tokyo Electric Power Company, Dr. Eng.}

Seismic Engineering Group, Nuclear Seismic Engineering Center, Nuclear Asset Management Department, Tokyo Electric Power Company, M. Eng.

General Manager, Project Management Department, Kobori Research Complex Inc., Dr. Eng. Manager, Project Management Department, Kobori Research Complex Inc., Dr. Eng.

Deputy General Manager, Structural Research Department, Kobori Research Complex Inc., Dr. Eng. 


\section{2. 実験内容}

\section{1 実験の位置付け}

本実験は，せん断波速度が $500 \sim 600 \mathrm{~m} / \mathrm{s}$ 程度の泥岩に支持された 平面 $80 \mathrm{~m} \times 80 \mathrm{~m}$, 高さ $60 \mathrm{~m}$ 程度の建屋に, $1 \mathrm{~g}$ 超光る水平加速度が入力 して浮き上がる状態を想定している。しかし，相似則を考慮すると $\lg$ 場の振動台でも遠心載荷装置でも，そこまで大型の構造物をモデ ル化できない。また，遠心載荷実験では入力最大水平加速度が $500 \mathrm{~cm} / \mathrm{s}^{2}$ 程度である。そこで, 実物換算でせん断波速度 $200 \mathrm{~m} / \mathrm{s}$ 程度 の支持地盤上に平面 $2.5 \mathrm{~m} \times 2.5 \mathrm{~m}$, 高さ $5.0 \mathrm{~m}$ の建屋模型を設置し, 地 震力が小さくても浮き上がり易く，また地盤の非線形現象が生じ易 い遠心載荷実験孛行っている。こ机は，必ずしも実建屋に生じる現 象を模擬している訳ではないが，実験装置の限られた条件下で現象 把握が可能な赛験として実施している。

\section{2 実験概要}

遠心模型による振動台実験の実験ケースを表 1 に，実験モデルと 計測点配置を図 1 に示寸。実験シリーズは, NS(支持地盤：砂)， $\mathrm{NC1}, \mathrm{NC2}, \mathrm{NC2U}$ (支持地盤：粘土)の 4 種類である。実験ケース名は, シ リーズ名 (NS, NC1, NC2, NC2U) に $10 \mathrm{~cm} / \mathrm{s}^{2}$ 刻みで丸めた $1 \mathrm{~g}$ 場換算の入 力加速度最大值を []で続けている。NSシリーズは, せ九断土槽 (加 振方向 $700 \mathrm{~mm}$, 幅 $220 \mathrm{~mm}$, 高さ $300 \mathrm{~mm}$ ) 内に空中落下法で作製した相詨 密度 $94 \%$ の乾燥豊浦砂上に, 平面 $100 \mathrm{~mm} \times 100 \mathrm{~mm}$, 高さ $200 \mathrm{~mm}$ 害物 $(\mathrm{g}$

表 1 遠心模型による実験ケース

\begin{tabular}{|c|c|c|c|c|c|c|c|}
\hline \multirow[b]{2}{*}{$\begin{array}{l}\text { 実 験 } \\
\text { ケース }\end{array}$} & \multicolumn{4}{|c|}{ 構造物模型(アルミニウム製) } & \multirow[b]{2}{*}{$\begin{array}{l}\text { 支持 } \\
\text { 地盤 } \\
\text { 模型 }\end{array}$} & \multicolumn{2}{|c|}{ 入力加速度波 } \\
\hline & $\begin{array}{c}\text { 高さ/幅 } \\
\mathrm{H} / \mathrm{L} \\
(\mathrm{mm})\end{array}$ & $\begin{array}{l}\text { 質量 } \\
\text { (kg) }\end{array}$ & $\begin{array}{l}\text { 底面 } \\
\text { 付着 }\end{array}$ & $\begin{array}{l}\text { 底面摩 } \\
\text { 擦係数 } \\
(1 \mathrm{G} \text { 場) }\end{array}$ & & 名称 & $\begin{array}{c}1 \mathrm{~g} \text { 場換算 } \\
\text { 最大加速度 } \\
\left(\mathrm{cm} / \mathrm{s}^{2}\right)\end{array}$ \\
\hline NS_30 & \multirow{11}{*}{$\begin{array}{c}200 \\
/ 100 \\
(5.0 \mathrm{~m} \\
(2.5 \mathrm{~m})^{* 1}\end{array}$} & \multirow{11}{*}{$\begin{array}{c}4.7 \\
(73 t)^{* 1}\end{array}$} & \multirow{3}{*}{ 無 } & \multirow{3}{*}{0.58} & \multirow{3}{*}{$\begin{array}{c}\text { 乾燥 } \\
\text { 豊浦砂 }\end{array}$} & \multirow{11}{*}{ 柏崎波*2 } & 30 \\
\hline NS_140 & & & & & & & 140 \\
\hline NS_470 & & & & & & & 470 \\
\hline NC1_30 & & & \multirow{3}{*}{ 無 } & \multirow{3}{*}{0.47} & \multirow{8}{*}{$\begin{array}{c}\text { カオリン } \\
\text { 粘土 }\end{array}$} & & 30 \\
\hline NC1_160 & & & & & & & 160 \\
\hline NC1_480 & & & & & & & 480 \\
\hline NC2_40 & & & \multirow{2}{*}{ 有 } & \multirow{2}{*}{-} & & & 40 \\
\hline NC2_470 & & & & & & & 470 \\
\hline NC2U_30 & & & \multirow{3}{*}{$\begin{array}{l}\text { 無 } \\
\text { (付着 } \\
\text { 切後) }\end{array}$} & \multirow{3}{*}{-} & & & 30 \\
\hline NC2U_220 & & & & & & & 220 \\
\hline $\mathrm{NC} 2 \mathrm{U} \_470$ & & & & & & & 470 \\
\hline
\end{tabular}

*1) 括弧内は実物 (1g場)に換算した值

*2） 2007 年新潟県中越沖地震における観測波 ${ }^{28)}$

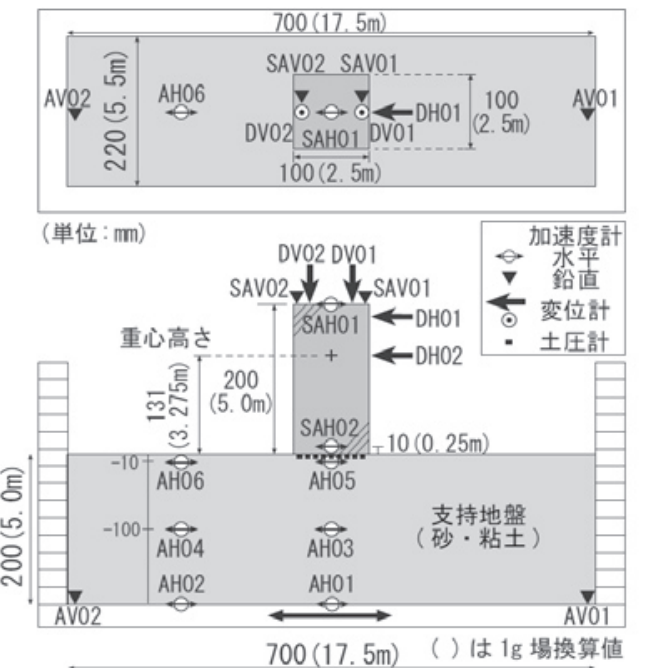

\section{加振方向}

$\mathrm{EB} 1 \sim \mathrm{EB} 9$

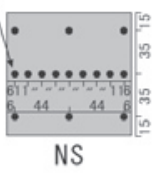

$\mathrm{EB} 1 \sim \mathrm{EB} 9$

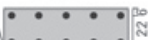

(1).

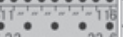

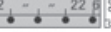

NC1

NC2

底面土圧計位置

図1遠心模型による実験モデルと計測点配置
場) 換算 : 平面 $2.5 \mathrm{~m} \times 2.5 \mathrm{~m}$, 高さ $5.0 \mathrm{~m}\}$ の剛体構造物模型を設置 $\mathrm{L}$, 遠 心加速度 $25 \mathrm{~g}$ 場で微小加振によりせん断ひずみ履歴を加えて平均せ 儿断波速度孛約 $200 \mathrm{~m} / \mathrm{s}$ 亿増加させた ${ }^{27}$ 後, 振動台実験老行った。 NC1 シリーズは，1g場で上記と同じせん断土槽内にカオリン粘土を最大 上載灾力 $638 \mathrm{kPa}$ で圧密した後，上記と同じ構造物模型を設置し，遠 心加速度 $25 \mathrm{~g}$ 場で振動台実験を行った。NC2シリーズは，1g場で構造 物模型を設置してカオリン粘土と構造物模型を同時に最大上載总 力 $638 \mathrm{kPa}$ で押してカオリン粘土を圧密した後, 遠心加速度 $25 \mathrm{~g}$ 場で 振動台実駼定行った。従って, NClでは構造物模型底面とカオリン粘 土の付着力は小さいが，NC2では大きな付着力が期待できる。NC2Uシ リーズは，NC2_470の加振で付着力が底面全体で切れた後，再度遠心 加速度 $25 \mathrm{~g}$ 場で振動台実験堂行ったケースである。これは，NC1シ リーズで底面の滑動の影響が顕著に現れため，付着力無で浮き上が りが顕著に生じる実験ケースとして実施したものである。

各実験ケース共に図 1 に示した配置で構造物・地盤の水平・鉛直 加速度，構造物の水平・鉛直変位及び底面土圧坴測定した。土圧計 は，支持地盤に乾燥砂を用いたNSシリーズでは構造物模型直下の砂 地盤中に 15 個埋め込み，支持地盤に粘土を用いた NC1, NC2, NC2Uシ リーズでは構造物模型に29個組込んでいる。なおる構造物底面上支 持地盤である砂及びカオリン粘土上の静的な摩擦係数は，的場にお

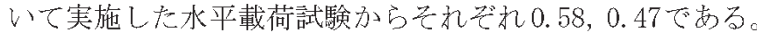

表2 相似比亡諸元

\begin{tabular}{c|c|c}
\hline \hline 物理量 & $\begin{array}{c}\text { 遠心 } \\
(25 \mathrm{~g} \text { 場 })\end{array}$ & $\begin{array}{c}\text { 実物 } \\
(1 \mathrm{~g} \text { 場 })\end{array}$ \\
\hline \hline 長さ & $1 / 25$ & 1 \\
\hline 質量 & $1 / 25^{3}$ & 1 \\
\hline 応力 & 1 & 1 \\
\hline 時間 & $1 / 25$ & 1 \\
\hline 振動数 & 25 & 1 \\
\hline 加速度 & 25 & 1 \\
\hline 速度 & 1 & 1 \\
\hline 変位 & $1 / 25$ & 1 \\
\hline 密度 & 1 & 1 \\
\hline \hline
\end{tabular}

\section{構造物模型}

\begin{tabular}{c|c|c}
\hline \hline 幅 $\mathrm{L}$ & $100 \mathrm{~mm}$ & $2.5 \mathrm{~m}$ \\
\hline 高さ $\mathrm{H}$ & $200 \mathrm{~mm}$ & $5.0 \mathrm{~m}$ \\
\hline 重心高さ $\mathrm{Hg}$ & $131 \mathrm{~mm}$ & $3.28 \mathrm{~m}$ \\
\hline 質量 & $4.7 \mathrm{~kg}$ & $73 \mathrm{ton}$ \\
\hline 慣性モーメト $\mathrm{Ig}$ & $1.77 \mathrm{~N} \cdot \mathrm{m}^{2}$ & $693 \mathrm{kN} \cdot \mathrm{m}^{2}$ \\
\hline 平均接地圧 & $115 \mathrm{kN} / \mathrm{m}^{2}$ & $115 \mathrm{kN} / \mathrm{m}^{2}$ \\
\hline \hline
\end{tabular}

\begin{tabular}{l||c|c|c}
\multicolumn{3}{l}{ 地盤模型 } \\
\hline \hline \multirow{3}{*}{ 層厚 } & $\mathrm{NS}$ & $199 \mathrm{~mm}$ & $4.98 \mathrm{~m}$ \\
\cline { 2 - 4 } & $\mathrm{NC} 1$ & $198 \mathrm{~mm}$ & $4.95 \mathrm{~m}$ \\
\cline { 2 - 4 } & $\mathrm{NC} 2$ & $204 \mathrm{~mm}$ & $5.10 \mathrm{~m}$ \\
\hline \multirow{3}{*}{ 密度 } & $\mathrm{NS}$ & $1.62 \mathrm{~g} / \mathrm{cm}^{3}$ & 同左 \\
\cline { 2 - 4 } & $\mathrm{NC} 1$ & $1.75 \mathrm{~g} / \mathrm{cm}^{3}$ & 同左 \\
\cline { 2 - 4 } & $\mathrm{NC} 2$ & $1.80 \mathrm{~g} / \mathrm{cm}^{3}$ & 同左 \\
\hline \multirow{3}{*}{ 平均Vs } & $\mathrm{NS}$ & $205 \mathrm{~m} / \mathrm{s}$ & 同左 \\
\cline { 2 - 4 } & $\mathrm{NC} 1$ & $202 \mathrm{~m} / \mathrm{s}$ & 同左 \\
\cline { 2 - 4 } & $\mathrm{NC} 2$ & $210 \mathrm{~m} / \mathrm{s}$ & 同左 \\
\hline \hline
\end{tabular}

表3 支持地盤材料の諸元

\begin{tabular}{c|c|c}
\hline \hline 物理量 & 豊浦砂 & カオリン粘土 \\
\hline \hline 土粒子密度 & $2.64 \mathrm{~g} / \mathrm{cm}^{3}$ & $2.61 \mathrm{~g} / \mathrm{cm}^{3}$ \\
\hline 平均粒径 & $0.38 \mathrm{~mm}$ & $0.001 \mathrm{~mm}$ 以下 \\
\hline 最大密度 & $1.67 \mathrm{~g} / \mathrm{cm}^{3}$ & - \\
\hline 最小密度 & $1.40 \mathrm{~g} / \mathrm{cm}^{3}$ & - \\
\hline 乾燥密度 $^{* 1}$ & $1.62 \mathrm{~g} / \mathrm{cm}^{3}$ & - \\
\hline 相対密度 & $94 \%$ & - \\
\hline 内部糜擦角 & $43^{\circ}$ & - \\
\hline 圧密荷重 & - & $638 \mathrm{kPa}$ \\
\hline 液性限界 & - & $86.5 \%$ \\
\hline 塑性限界 & - & $30.8 \%$ \\
\hline 塑性指数 & - & $55.7 \%$ \\
\hline \hline
\end{tabular}

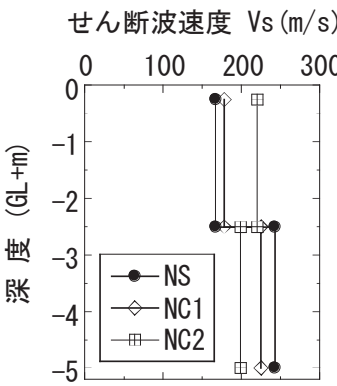

図 2 支持地盤 せん断波速度分布 ( $1 \mathrm{~g}$ 場換算)
*1）せん断ひずみ履歴付与後

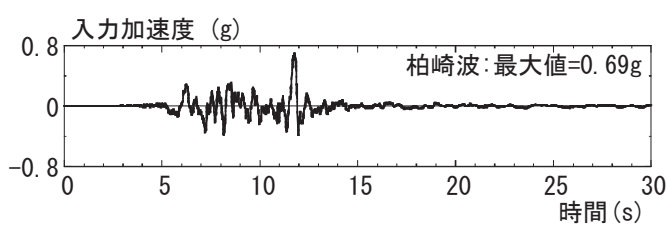

図3 入力加速度時刻歴 ( $1 \mathrm{~g}$ 場換算 $)^{28)}$ 
$25 \mathrm{~g}$ 場における相似比之構造物模型・地盤材料の模型・実物におけ る諸元を表 2 , 表 3 亿示す。構造物模型は質量 $4.7 \mathrm{~kg}$ のアルミニウム 製で，ロッキングの影響が卓越するように高さ幅比を 2 上した。支 持地盤は，平均せん断波速度が概敉 $200 \mathrm{~m} / \mathrm{s}$ になるように砂地盤には せん断ひずみ履歴を加え, 粘土地盤では圧密圧力夌調整して作製し た。25g 場に秎ける振動台実駼の直前にパルス波を人力して測定し たせん断波速度分布を図 2 に, 支持層全深度の平均值を表 2 に示 す。平均せん断波速度はいずれのシリーズも概ね $200 \mathrm{~m} / \mathrm{s}$ 上なってい るが，砂地盤では浅層で小さくなる傾向が最も顕著である。

実験に用いた入力加速度時刻歴を $1 \mathrm{~g}$ 場に換算して図 3 亿示卞。人 力结，2007年新潟県中越沖地震に沶汁る柏崎 - 刈羽原子力発電所 1 号機原子吙建屋基礎版上で観測された $\mathrm{EW}$ 成分 (1R2. $\mathrm{EW}^{28)}$ ，柏崎波と 略称)であり，観測記録の時間上加速度振幅を調整して用いた。最大 加速度振幅は表 1 亿示寸 3 種類 $\left\{\right.$ 小加振 $\left(30 \sim 40 \mathrm{~cm} / \mathrm{s}^{2}\right)$, 中加振 $(140$ $\left.\sim 220 \mathrm{~cm} / \mathrm{s}^{2}\right)$, 大加振 $\left(470 \sim 480 \mathrm{~cm} / \mathrm{s}^{2}\right)$ ) とした。また, 以後の実験結 果は全て実物 $(\mathrm{lg}$ 場) に換算して表示している。

\section{3. 小加振実験結果}

\section{1 構造物の応答}

4 シリーズの小加振実験に抒ける構造物頂部水平加速度 [SAH01，構造物鉛直加速度 [(SAV01+SAV02)/2]，周辺地盤地表水平 加速度 $[\mathrm{AHO6}]$, 振動台人力水平加速度 $[\mathrm{AHO1}]$ の主要な 11 秒間を図 4 に示寸。NS_30の構造物頂部水平加速度が小さい部分が他と大きく 異なっている。また，構造物の鉛直加速度注いずれも水平加速度の 1/10以下と小さい。
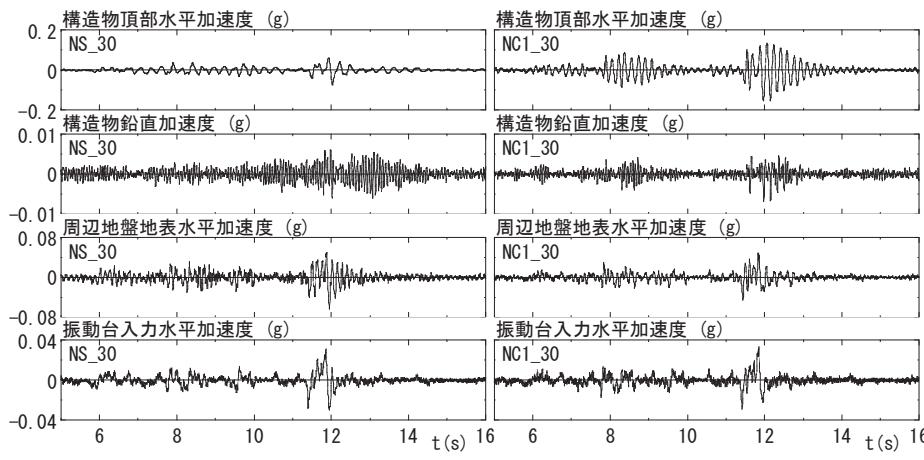

(a) NS_30: 支持地盤砂 (付着無)
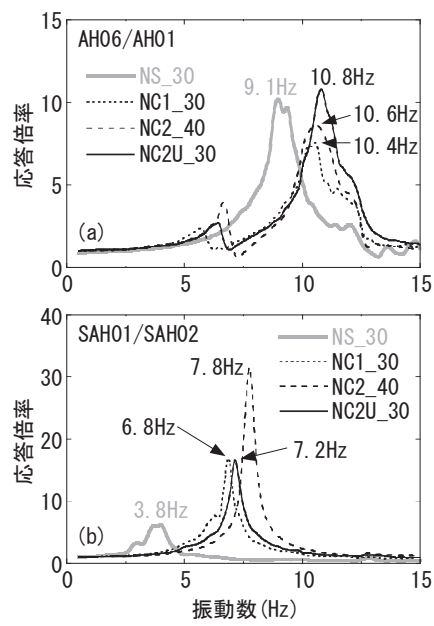

図5 小加振実験にお性る フーリエスペクトル比

(b) NC1 30: 粘土 (付着無)
図4 小加振実験における代表的な応答時刻歴
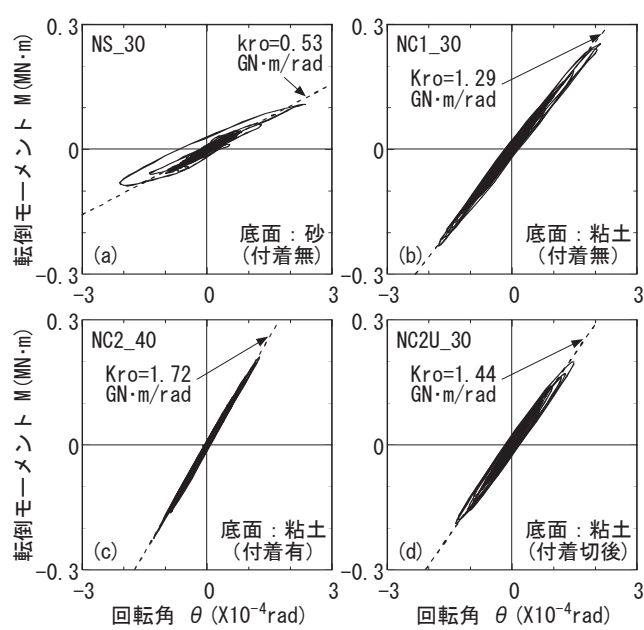

図6 小加振実験における構造物 伝倒モーメントと回伝角の関係
振動台入力加速度に対寸る周辺地盤地表加速度 (AH06/AHO1), 構 造物底部加速度に対寸る構造物頂部加速度 (SAH01/SAH02)のフーリ エスペクトル比を図 5 に示す。地盤の 1 次ピーク振動数は，支持地 盤が秒のNS_30では9.1Hz付近に，支持地盤が粘土のケースでは 10.4 $\sim 10.8 \mathrm{~Hz}$ 付近に存在し，支持地盤吕砂の方がやや低い傾向が認めら れる。1/4波長則から求めたせん断波速度は約 $182 \sim 216 \mathrm{~m} / \mathrm{s}$ で, 表 2 , 図 2 の関倸と概和対応している。一方, 構造物の 1 次ピーク振動数 は支持地盤が砂のNS_30では3. 8Hz 付近に, 粘土の各ケースで注6.8 $\sim 7.8 \mathrm{~Hz}$ 付近々存在し，支持地盤が砂の方が約 $1 / 2$ 上明らかに低い。 これは, 砂のせん断剛性が上載圧に依存寸るため地表付近で非常に 小さいことが影響していると考它られる。なおう，秒のせ九断剛性が 地表付近で小さいため，NS_30では非線形性の影響でピーク振動数 が低下しているむの上考えられる。

\section{2 構造物のスウェイ・ロッキング挙動}

4 シリーズの小加振実験における構造物転倒モーメントと回転 角の関係孛図 6 に, 構造物底面せん断力上, 構造物底面上周辺地盤 の相対変位の関係䘮図 7 に示す。図6の傾きはロッキングば敉に, 図 7 の傾きはスウェイば和に相当する。NS_30ではルーブを描いて 非線形化しているが，NC1_30,NC2_40,NC2U_30で法非線形化の影響 は小さく，特にNC2_40ではループ面積の小さな関係が得られてい る。NS_30は両ばね共に明らかに小さく，支持地盤が粘土のケースで は構造物底面付着が有るNC2_40が最も大きくなっている。これらの 大小関倸浪，図５に示したフーリエスペクトル比の 1 次ピーク振動 数の大小関係上整合している。NS_30の両ばねが小さいのは，砂のせ

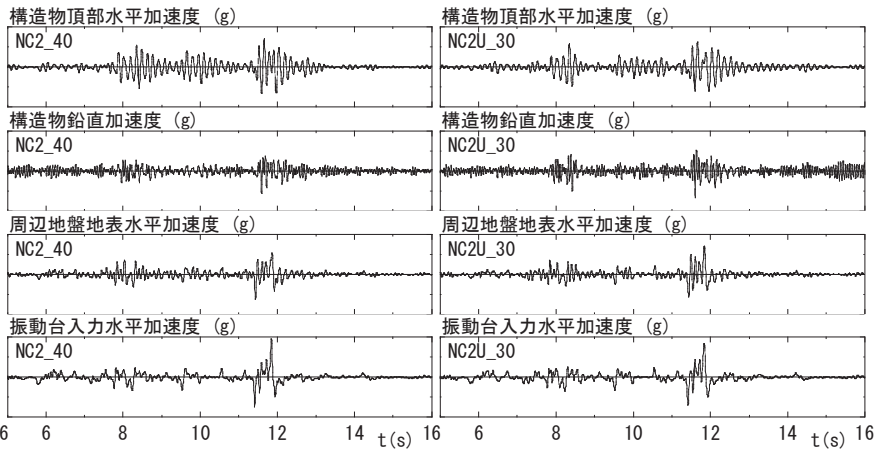

(c) NC2_40:粘土(付着有) (d) NC2U_30:粘土 (付着無: 切後)
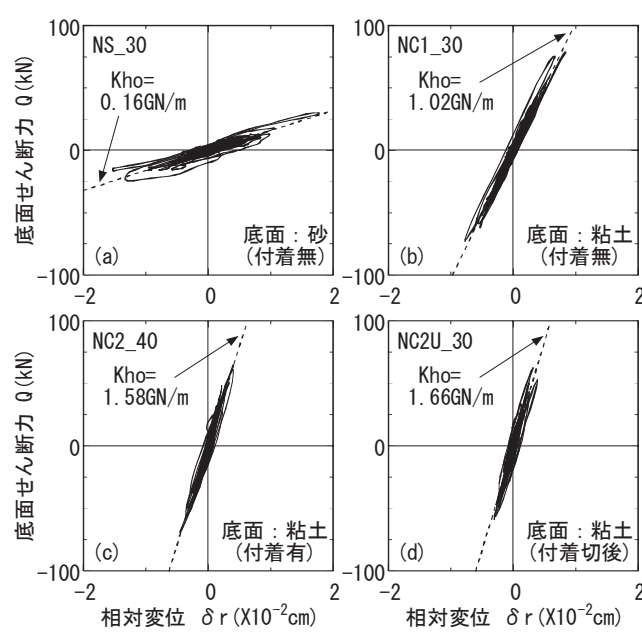

図7 小加振実験にお打る構造物底面せん断力 と相対変位 (構造物底面一周辺地盤) の関係 


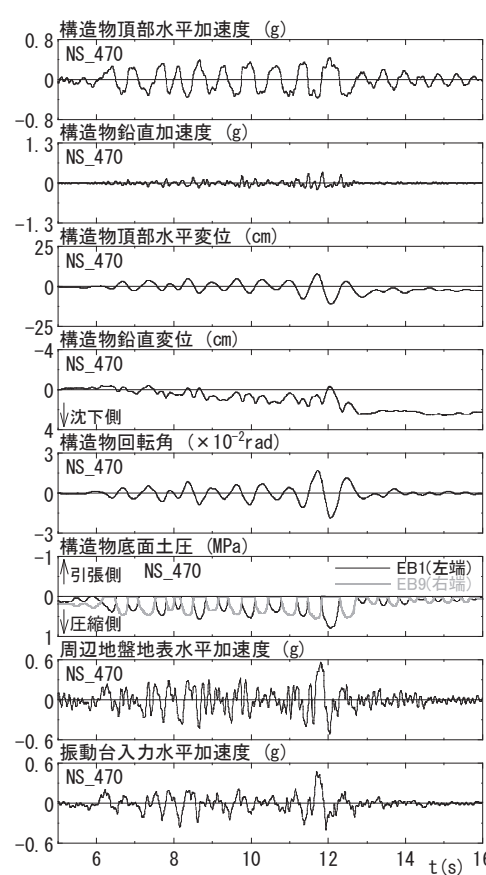

(a) NS_470: 支持地盤砂 (付着無)

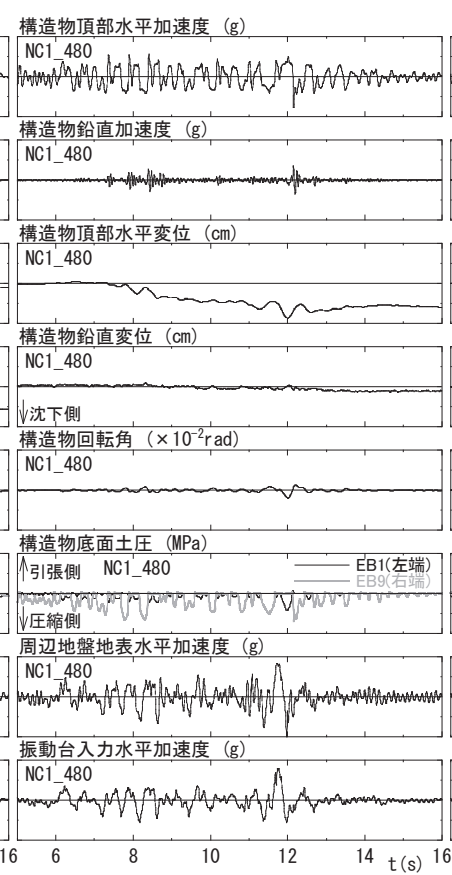

(b) NC1_480: 粘土(付着無)
構造物頂部水平加速度 $(\mathrm{g})$

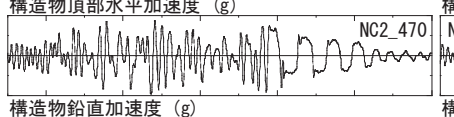

構造物項部水平加速度 $(\mathrm{g}$

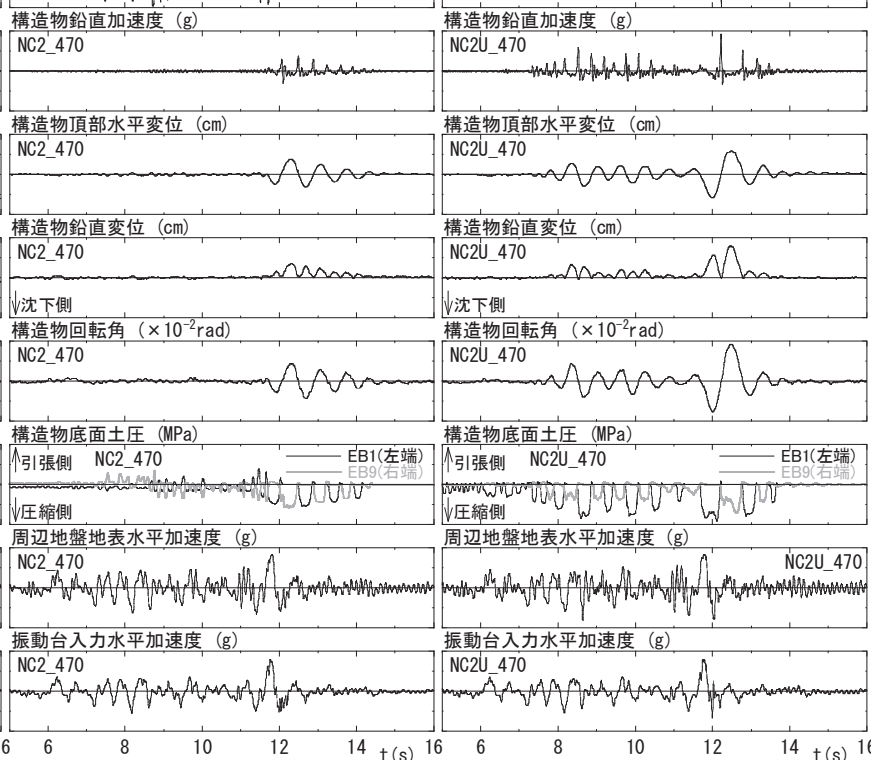

(d) NC2U_470:粘土(付着無: 切後)

図8 大加振実験における代表的な応答時刻歴

ん断剛性が上載圧に依存して大きくなるため地表付近で非常に小 さいことが影響していると考えられ，支持地盤の平均せん断波速度 が同一でも，支持地盤が乾燥砂の場合上粘土の場合で構造物のス ウェイ・ロッキング挙動が異なることを示唆している。

\section{4. 中 · 大加振実験結果}

\section{1 構造物の応答}

大加振実験における構造物頂部水平加速度, 構造物鉛直加速度, 構造物頂部水平変位 [DH01], 構造物鉛直変位 $[$ (DV01+DV02)/2], 構造 物回転角 [(SAV01-SAV02)/Lの 2 回積分, L はセンサ一間距離)，底面 土圧 $[\mathrm{EB} 1, \mathrm{~EB} 9$, 両端 $]$, 周辺地盤地表水平加速度, 振動台大力水平加 速度の主要な 11 秒閒を図 8 に示扵。底面土圧は動的応答成分上初期 土圧成分の和である。

4 ケースの振動台大力水平加速度と地表水平加速度時刻歴はを れぞれほぼ同一上認められ，地盤応答に大きな差異はない上考えら れる。また，底面土圧注両端で逆方向 (異符号) となり，NC2_470の 12 秒までを除けば引張り側でほぼ零になる上共に，構造物鋯直変位が NS_470(全体的には沈み込みながら)，NC2_470，NC2U_470では上方 に大きくなり，浮き上がりが生じている。ただし，支持地盤が砂の NS_470で恃引張り側土圧は全く生じていないが，支持地盤が粘土で 底面付着が無いNC2U_470では土圧が零になる直前に小さいながら も引張り側土圧が発生しており，底面付着が無いケースでも小さい ながら付着力が存在し，その影響で土圧特性に支持地盤による差が 生じているものと判断される。支持地盤が砂のNS_470では, 浮き上 がりによって構造物頂部水平加速度が 6 秒付近から長周期化し, 構 造物頂部水平変位と回転角が増加している。支持地盤が粘土で底面 付着が無いNC1_480では, 浮き上がりが生じて構造物頂部水平加速 度が長周期化している時刻で構造物鉛直加速度がスパイク状に発 生しているが，底面の滑りが卓越して構造物回転角は増加していな い。一方, 支持地盤が粘土で底面付着が有るNC2_470では, 底面付着 力が刹いていると考えられる12秒付近までは引張り側でも底面土
圧が発生し，構造物頂部水平変位や回転角が非常に小さいが，12秒 付近で付着が切れる上構造物頂部水平加速度が長周期化寸る上共 に構造物頂部水平変位上回転角が急激に増加し，同時に構造物鉛直 加速度がスパイク状に増大している。支持地盤が粘土で初期から付 着力が無いNC2U_470では，底面で滑動が生じていないため浮き上が りが顕著に生じ，8秒付近から構造物頂部水平加速度が長周期化す ると共に構造物頂部水平変位，回転角が増加し，同時に構造物鉛直 加速度がスパイク状に増大して構造物頂部水平加速度よりも大き くなっている。

このように，地表付近の地盤剛性が砂地盤に比べてより大きな粘 土地盤では，浮き上がり後の再接地の際の衝撃が大きく，構造物鉛 直加速度はより大きくなるものと判断される。

\section{2 構造物の浮き上がり挙動}

NC2_470の底面付着が切れて浮き上がりが生じ始める $11.5 \sim 13.5$ 秒に括ける代表的な応答時刻歴堂拡大して図 9 亿示寸。な抒，特定 の時刻の現象を見比ぶるため，図中には縋に破線を引いている。 11. 7秒付近で底面土圧が低下し始め，11.95秒付近で完全に零にな り底面付着が切れ, 構造物回転角が急激に増大し, 回転角に連動し て構造物鉛直変位孞上方に増加している。また, 構造物頂部水平加 速度及びそれ仿存寸る転倒モーメントや底面せん断力は山がつ ぶれて一定值上なる傾向が明らかである。底面土圧は, 両端のEB1 上 EB9が交互に引張側でほ注零となり，付着力が消失してることが分 かる。な拉，土圧が零になる直前に小さいながらも付着力の影響で 引張り側土圧が生じていることが確認できる。また，両端の土圧が 入れ替わる回転角がほほ淮零の時に，中央部の土圧EB5が瞬閒的に圧 縮側で大きくなる。EB3とEB7 はEB5より少し早くあるいは少し遅く 圧縮側の土圧が生じて和り，順番に中央付近の土圧が大きくなって いることが分かる。引張り側土圧が零の状態を浮き上がり上判断 し, 加振方向中央に並ぶ9個の土圧計加ら求めた構造物接地率は, 構造物回転角に連動して低下している。構造物鉛直加速度は，回転 


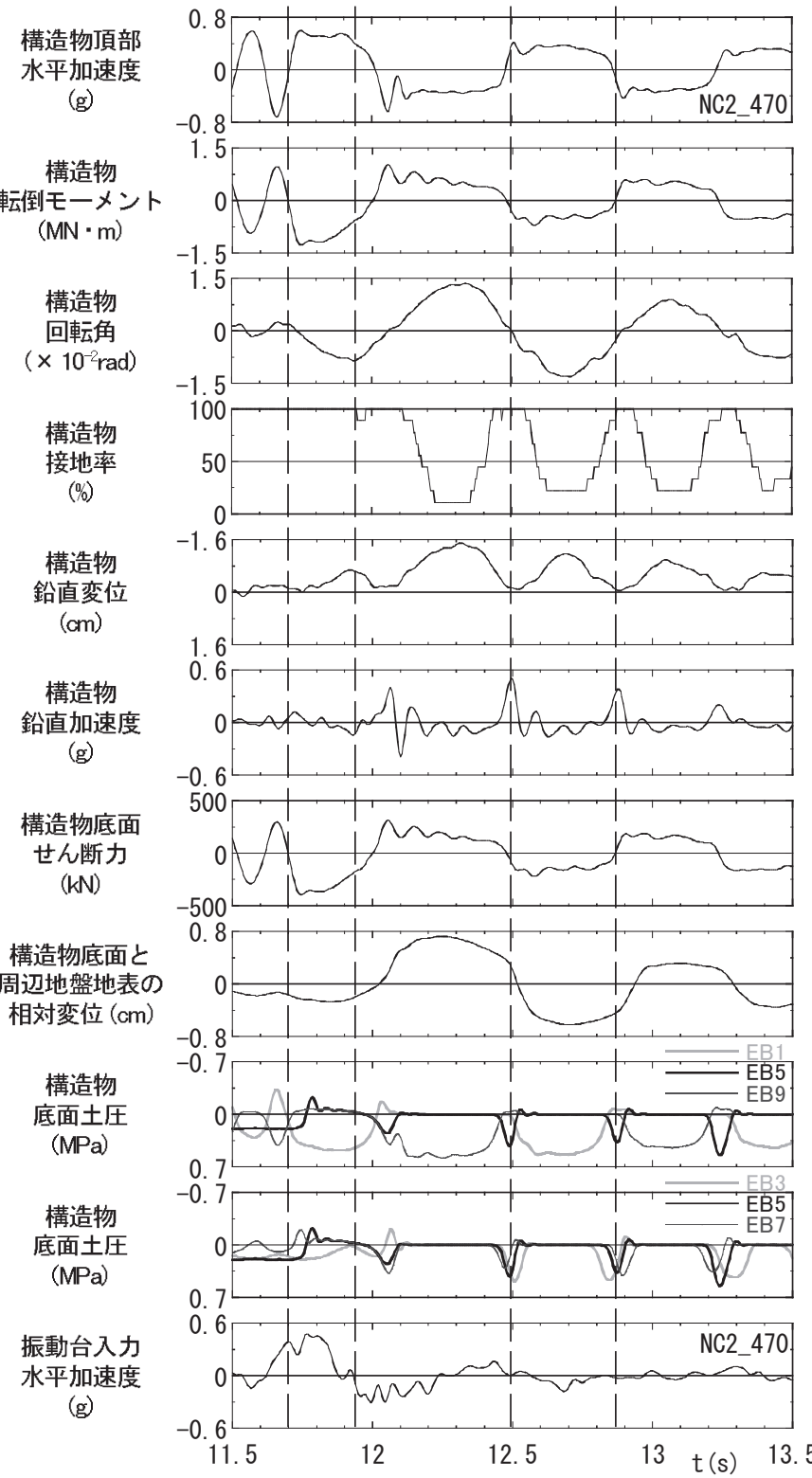

図9 代表的な心答時刻歴 ( $\mathrm{NC} 2 \_470$ : 支持地盤粘土(付着有))
角がほぼ零付近で正側（重力加速度方向）に生じていることが明ら かである。

\section{3 構造物のスウェイ・ロッキング挙動}

中加振実験 3 ケースの転倒モーメントと回転角の関倸莸図 $10 k$ に, 接地率と回転角の関倸学図11 亿示寸。図10 亿注図6で求めた小加振 時の傾き $\mathrm{K}_{\mathrm{r}}$, 次式に示寸限界転倒モーメント $\mathrm{M}_{\max }$ ，転倒モーメント $\mathrm{M}$ 上回転角 $\theta$ の関係 (JEACA601-2008 ${ }^{1 \mathrm{1E})}$, 以後JEAC 上略称) 老, 図 11 に ほ接地率に関寸るJEACの評価式 $(\alpha=6.0)^{19)}$ 老併記している。

$$
\begin{array}{rlrl}
\mathrm{M}_{\text {max }} & =\mathrm{W} \frac{\mathrm{L}}{2} & \\
\frac{\mathrm{M}}{\mathrm{M}_{0}} & =\frac{\theta}{\theta_{0}} & & \theta \leqq \theta_{0} \\
& =\frac{\alpha}{2}-\frac{\alpha-2}{2} \cdot\left(\frac{\theta_{0}}{\theta}\right)^{2 /(\alpha-2)} & & \theta>\theta_{0} \\
\mathrm{M}_{0} & =\mathrm{W} \frac{\mathrm{L}}{\alpha} & & \theta \leqq \theta_{0} \\
\eta & =1 & \theta>\theta_{0}
\end{array}
$$

ここに, Wに構造物重量， $\mathrm{L}$ は構造物基礎幅， $\mathrm{M}_{0}$ は浮き上がり限界 転倒王一メント， $\theta_{0}$ は浮き上がり限界回転角， $\alpha$ は地反力分布に応

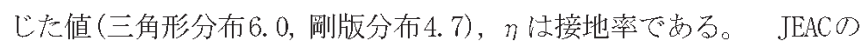
評価式の初期回転地盤壮社 $\mathrm{K}_{\mathrm{r} 0}$ 注図 6 から得られた值とし, 浮き上 がり限界回転角 $\theta_{0}$ は支持地盤が砂の場合はNS_470, 粘土の場合は NC1_480(NC1シリーズ),NC2U_470(NC2, NC2Uシリーズ)で最初に両 端部土圧 (EB1，EB9)のどちらかに浮き上がりが認められた構造物回 転角とした。転倒モーメントは回転角の増大に伴って緩やかに剛性 低下し、履歴ループが膨らんでいることが分かる。この剛性低下上 履歴ルーブの膨らみは接地率の低下とほぼ連動している。また， NC1_160 と NC2U_220の転倒モーメントとJEACの評価式はほぼ対灾し ている。一方，NS_140は図6でも指摘したように支持地盤の剛性低 下の影響が顕著なため，JEACの評洒式とは一致していない。

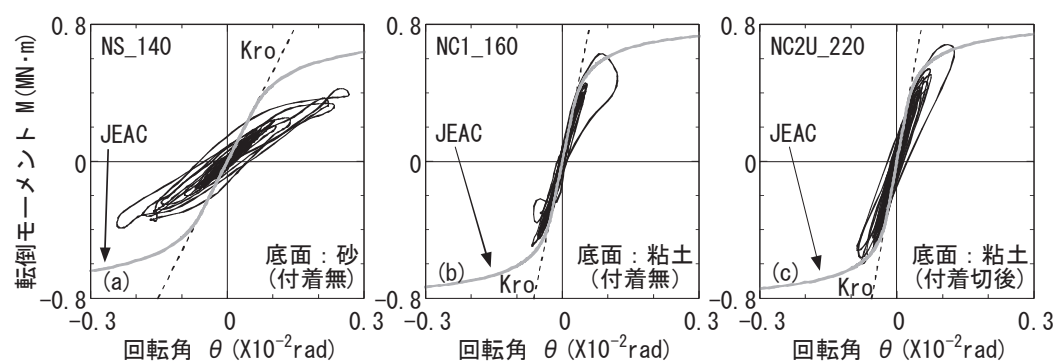

図10 中加振実験における構造物転倒モーメントと回転角の関係

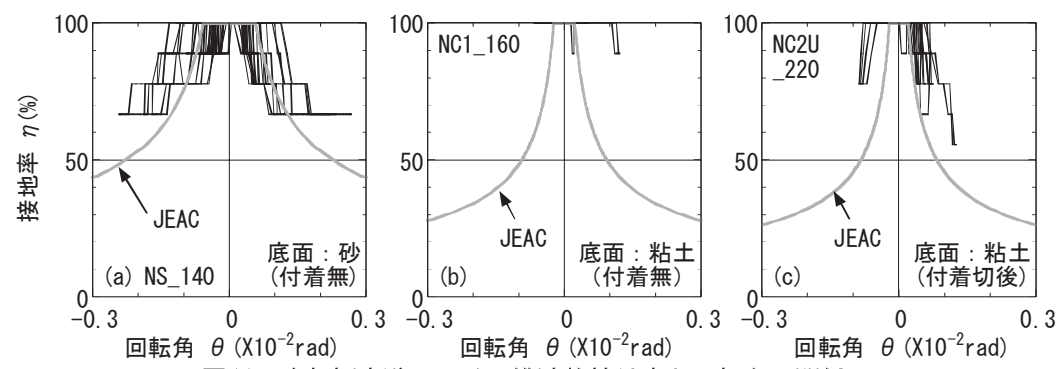

図11 中加振実験に㧍ける構造物接地率と回転角の関係
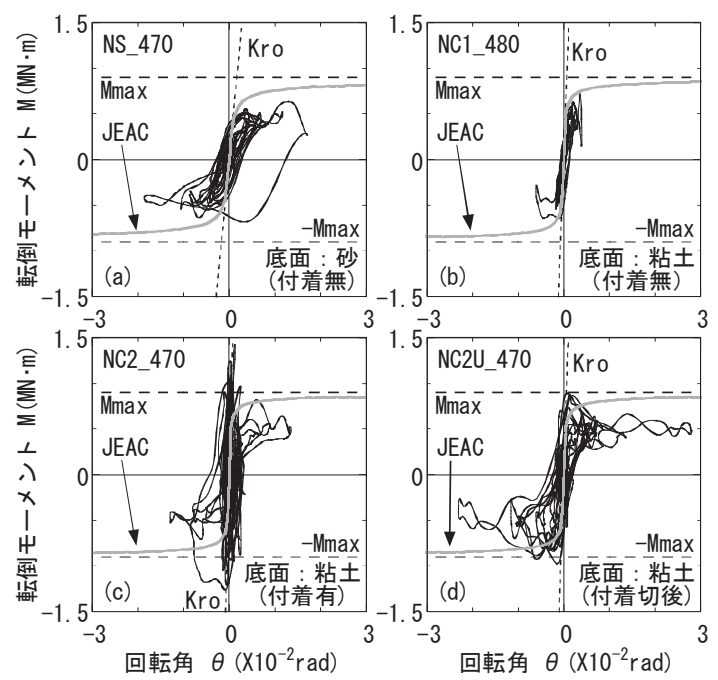

図12 大加振実験に扝ける構造物 転倒モーメントと回転角の関保 
大加振実験 4 ケースの転倒モーメントと回転角の関倸を図 12 に,

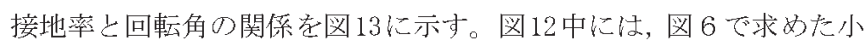
加振時の傾き $\mathrm{K}_{\mathrm{r}}$ ，(1)式に示寸限界転倒モ一メント $\mathrm{M}_{\text {max }}$ ，転倒モーメ ントM と回転角 $\theta$ に関寸るJEACの関倸 $\left.{ }^{19}\right)^{\text {t }}$, 図 13 中には接地率と回 転角に関寸るJEACの評価式 $(\alpha=6.0)^{19)}$ を垪記している。NS_470, NC1_480では, 回転角の増加に伴い構造物が浮き上がり, 転倒モ一メ ントが降伏して S 字型の履歴となって $\mathrm{M}_{\max }$ を明らかに下回ってい る。この傾向は, 支持地盤が粘土のNC1_480より砂のNS_470の方が顕 著であると共に, 支持地盤が砂の方が減衰が大きな履歴ループを描 いている。また，転倒モ一メントの降伏に対応して図13に示した接 地率が低下している。一方, 構造物底面に付着が有るNC2_470では, 図 9に示したように11.95秒付近まで付着が効いて浮き上がりが生 じていないため， $\mathrm{M}_{\text {max }}$ 超える転倒モーメントが発生しているが， 11.95秒以降は付着が切れたため, 転倒モーメントが降伏してS字 型の履歴となっている。付着が切れた後に再度加振したNC2U_470で は，ほぼ $\mathrm{M}_{\text {max }}$ まで達するもののほとんど超えることは無く，回転角の 増大に従って $\mathrm{M}_{\max }$ より小さくなっていることが分かる。NC2_470, NC2U_470の転倒モ一メントとJEACの評価式を比べると, 回転角が小 さく引張り側土圧が生じている場合にJEAC上り大きな転倒モ一メ
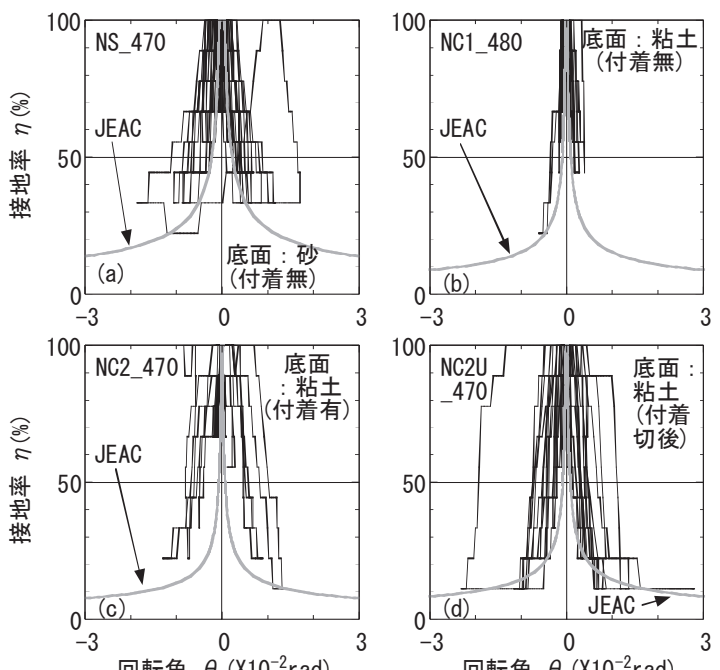

図13 大加振実験における構造物接地率と回転角の関係
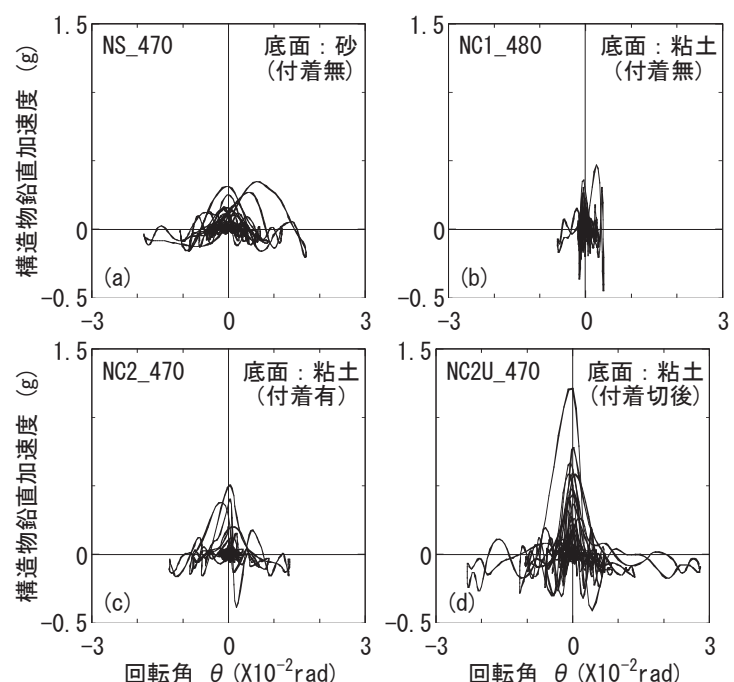

図 15 大加振実験における構造物鉛直加速度と回転角
ントが発生しているが，その後回転角の増加に伴い逆にJEACより小 さくなる傾向が認められる。転倒モーメントが小さくなるのは，P〜 $\delta$ 効果に上り回転角 $0.02 \mathrm{rad} ゙ 5 \%$ 程度の低減はあるものの, 多くは 構造物が地盤内に沈多込むことで回転中心が基礎端より少し内側 に移動し，(1)式のL/2が相対的に小さくなった影響 ${ }^{29)}$ と判断され る。

このように, 底面付着力が存在することで構造物に $\mathrm{M}_{\text {max }}$ を超える 転倒モーメントが発生し，浮き上がり莸抑える効果があることが実 駼的化確認された。また，図13に示した接地率は回転角が $0.005 \mathrm{rad}$ 程度まで急激に低下寸るがその後緩やか低下し，この傾向はJEAC の評価式と一致している。また，JEACの評価式は概水実験結果の下 限にあり，最小接地率を示していると判断される。

構造物鉛直変位上回転角の関係を図 14 に示寸。図中には，地盤上 構造物を剛体上仮定した場合の関係学破線で併記している。支持地 盤が粘土のNC1_480,NC2_470,NC2U_470では，破線よりやや下側を 沿って扮り，粘土地盤に僅かに沈み込みながら浮上っている上判断 される。一方, 支持地盤が砂のNS_470では図8に示したように繰返 しの回転灾答に対して支持地盤中に構造物が沈み込んでいる。しか し，全体として沈み込みながらも回転角の増大に従って破線上ほぼ
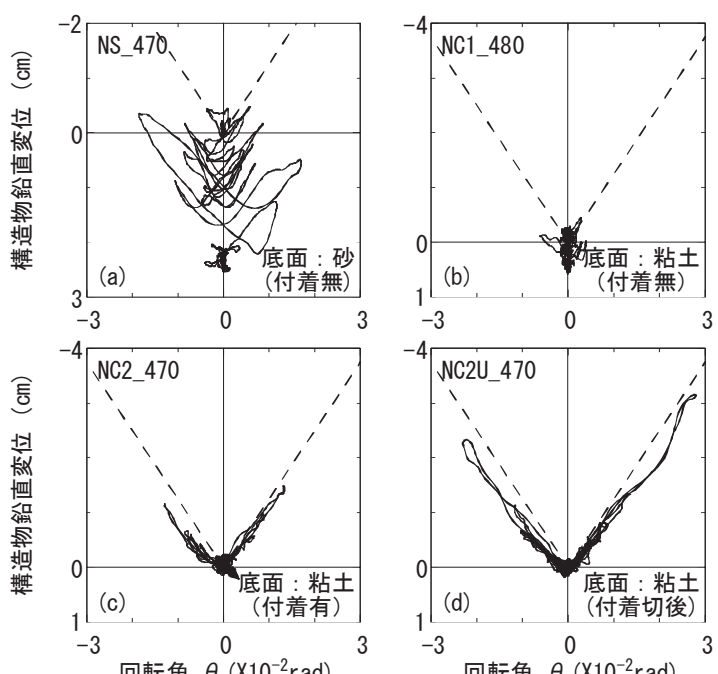

図14大加振奏験に拉ける構造物鈶直変位と回転角の関係

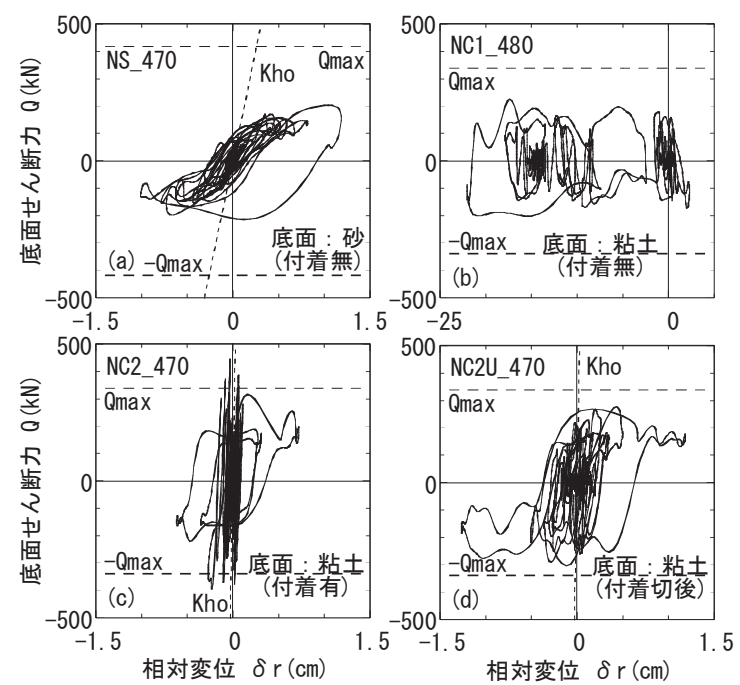

図16 大加振実験にお引る構造物底面せ九断力と相対変位の関係 

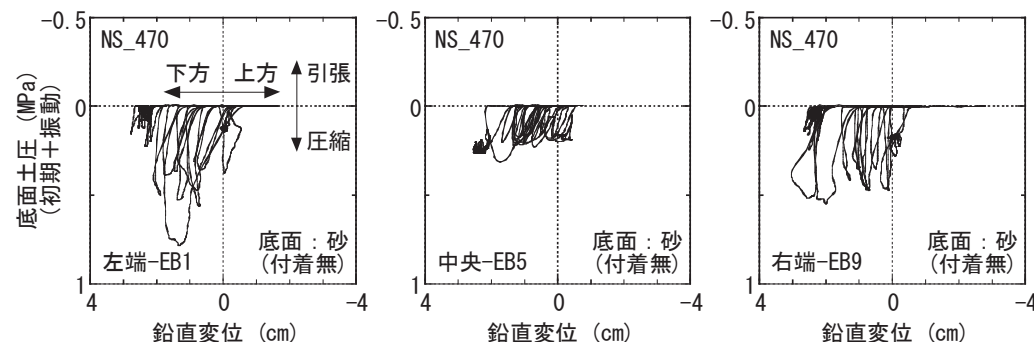

（a-1）底面土圧 (初期十振動) 乙鈆直変位の関係(順に左端，中央，右端）
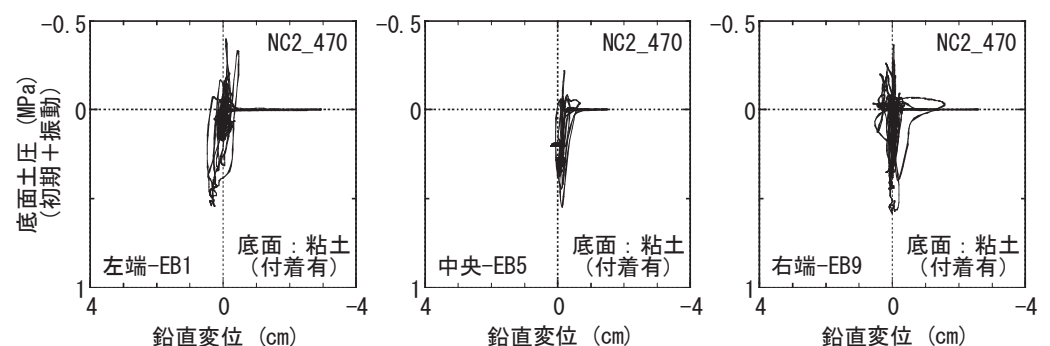

(b-1) 底面土压 (初期十振動) と鉛直変位 関係(順に左端，中央，右端）
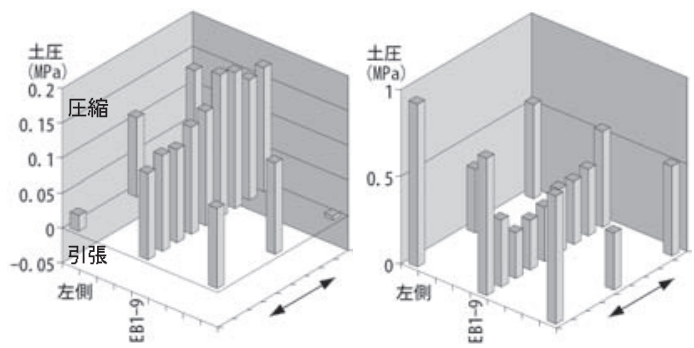

（a-2）底面最大土圧分布 (左: 初期，右：初期十振動)
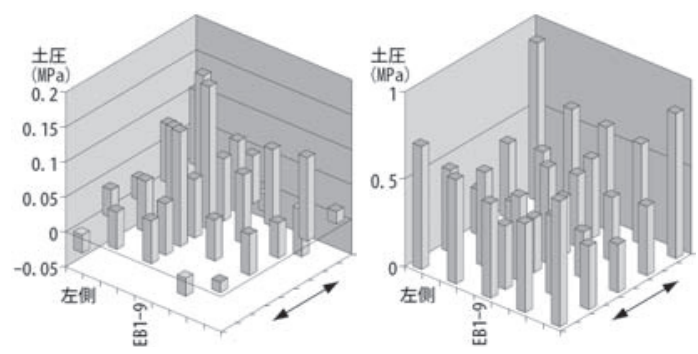

(b-2) 底面最大土圧分布 (左: 初期, 右: 初期 + 振動)

図17大加振実験に㧍ける構造物底面土圧と構造物鈆直变位の関係上構造物底面最大土圧分布（上かからNS_470, NC2_470）

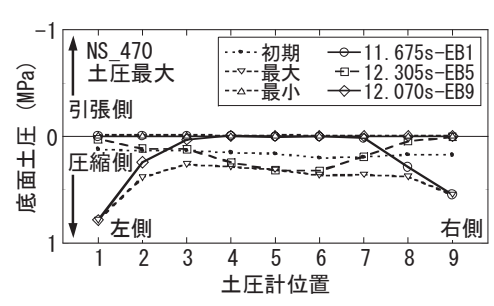

(a) NS_470: 支持地盤砂 (付着無)

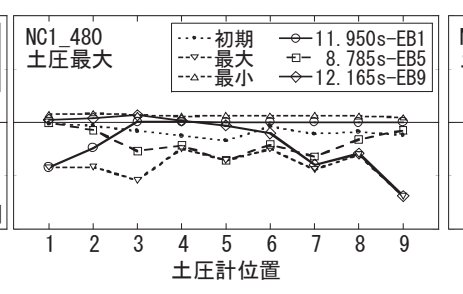

(b) NC1_480:粘土(付着無)

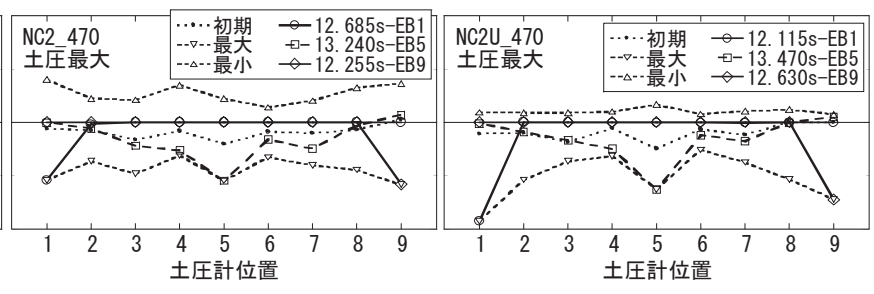

(c) NC2_470: 粘土(付着有)

(d) NC2U_470: 粘土 (付着無: 切後)
平行に構造物鉛直変位が増加し，浮き上がりが生じていることが分

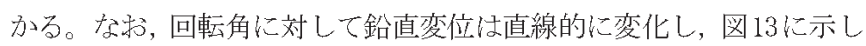
た接地率は最初急激に変化寸るため傾向は異なるが，両図はほぼ対

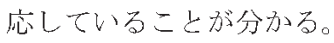

構造物鉛直加速度上回転角の関係孛図15亿示寸。図 9 で指摘した ように，回転角がほぼ零の時に再接地による衝撃で正側に極端に大 きくなると共に, 回転角の増大により構造物重心位置が高くなる影 響で負側の值となる傾向が認められる。この鉛直加速度の発生は,

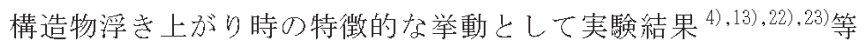
に基づき従来から指摘されている現象である。

構造物底面せん断力と, 構造物底面と周辺地盤地表の相対変位の 関係を図16亿示寸。図中には図7 で求めた小加振時の傾き $\mathrm{K}_{\mathrm{h} 0}$ 上 $1 \mathrm{~g}$ 場で測定した摩擦係数で滑る場合の最大底面せん断力 $\mathrm{Q}_{\max }$ 老併記し ている。NC1_480 は実験時の観察から明らかに構造物が滑ったこと が確認されているが, 得られた底面せん断力は1g場で測定した静的 な摩擦係数より小さな值である。砂地盤では，1g場で測定した静的 な摩擦係数上遠心場 (25g)の動的な摩擦係数がほぼ一致することを 確認している ${ }^{29)}$ が，粘土では1g場で実施した摩擦試験には小さいな がらも付着力の影響孞含まれ，遠心場に招ける摩擦倸数学過大評価 したものと考えられる。一方, 粘土地盤上の付着が有るNC2_470で は， $\mathrm{Q}_{\text {max }}$ 超它る底面せ九断力が生じており，付着力による影響と判 断される。また, NS_470,NC2U_470で圭, 浮き上がりに上り構造物加 速度が頭打ちになったため， $\mathrm{Q}_{\max }$ より小さな底面せん断力で収まっ たものと判断される。

\section{4 底面土圧}

NS_470上NC2_470の加振方向中央に9 個並ぶ土圧計の両端及び中 央の土圧上, 土圧計位置に䄧ける構造物鉛直変位の関倸, 及び遠 心加速度25gを載荷した状態における全底面土圧 (加振前の初期成 分), 並びに加振時の全底面土圧 (初期成分含む) の最大值分布を図 17亿示寸。支持地盤に砂を用いたNS_470では, 引張側の土圧が零 となって鉛直変位だけが変動しており，浮き上がりにより引張側 の土圧が全く生じていないことが分かる。また，圧縮側の土圧法 図14に示したように構造物が沈み込みながら生じている。一方, NC2_470では明らかに引㲀側でも土圧が生じているが，土圧一定で 鉛直変位だけが変動している部分も認奻られる。これは加振の途 中で付着が切れたためである。

遠心加速度25g載荷した初期状態の底面土圧は, 支持地盤が砂 のNS_470では中央部分がやや大きく, 粘土のNC2_480ではかなり大 きくなる傾向が認められる。また，加振による最大土圧法いずれ も加振方向両端部で大きくなる傾向が認められる。

大加振実験 4 ケースの底面土圧 (加振方向の中央に並ぶ 9 個)の 初期值, 最大值 (圧縮) と最小值 (引張) の分布と, 両端と中央の底面 土圧が最大值を示す時刻の分布を図 18 に示す。支持地盤が砂の NS_470では引張側土圧が殆んど生じていない。一方, 支持地盤が粘 土で付着力が無いNC1_480やNC2U_470では小さい引張側土圧が生じ ているが，付着力が有るNC2_470で注明らかに大きな引張側土圧が 生じている。また, 圧縮側土圧は両端上中央で大きくなる傾向が認 わられる。両端の底面土圧が最大となる時刻では, 端から 1 個ある 
いは2 個の土圧計のみで圧縮側土圧が生じ, 残りの7〜8個の土圧 計はほぼ零上なって明らかな浮き上がりが認方机る。一方，中央 の土圧計が最大となる時刻では両端の土圧がほぼ零になっている がそそれ以外の土圧は圧縮側の值を走し，NC2_470，NC2U_470では中 央の土圧計で特に大きな圧縮側の值を示していることが分かる。こ れは，両端部の地盤が沈下して地盤面が円弧状になったため上推察

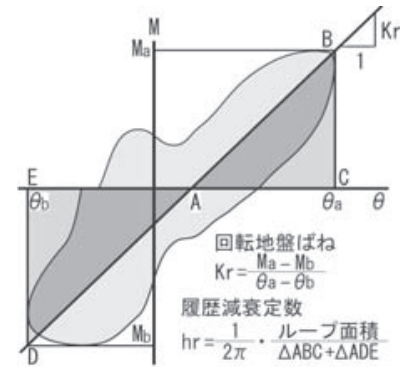

図19地盤泟水定数々 履歷減衰定数の定義
される。

5. 底面地盤ばねの非線形特性

\section{1 底面回転地盤ばね}

図6,図10や図 12 に示した構 造物転倒モーメントと回転鱼の 履歴ループから，転倒モーメン トの零クロスによってルループ 毎に分解し, 図19に示扵定義に 従つて回転地盤ば称 $K_{\mathrm{r}}$ 上履歴減 衰定数 $h_{\mathrm{r}}$ 算出した。算出方法は 文献 ${ }^{30)}$ に示されているJGS
0542-2009「地盤材料の変形特性を求わるための繰返し三軸試験方 法」に従っているが, 応答值から算出した転倒モーメント上回転角 の履歴ループの最大值や最小值の時刻は必ずしも一致しないため ループが丸まってしまう。そこで，回転地盤ばれは，両者の最大值・

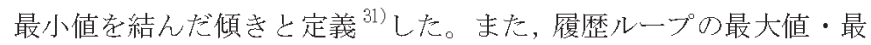
小值の符号が同じ場合や符号が異なっていてもその比が $1 / 10$ 以下 のデー夕， $\theta$ が $5 \times 10^{-6}$ 以下のデー夕除いた。得られた結果を支持 地盤声砂の場合, 粘土で底面付着が無い場合と有る場合に分けて図 20 に示す。図中には，(5)式に示打JEAC 0 評価式 $(\alpha=6.0)^{18)}$ 老併記 した。（5）式は支持地盤老弾性体上仮定し，浮き上がりによる幾何学 的非線形の双起考慮した関倸である。

$$
\begin{aligned}
\mathrm{K}_{\mathrm{r}} & =\mathrm{K}_{\mathrm{r} 0}=\frac{\mathrm{M}_{0}}{\theta_{0}} & \theta \leqq \theta_{0} \\
& =\mathrm{K}_{\mathrm{r} 0} \frac{\theta_{0}}{\theta}\left\{\frac{\alpha}{2}-\frac{\alpha-2}{2} \cdot\left(\frac{\theta_{0}}{\theta}\right)^{2 /(\alpha-2)}\right\} & \theta>\theta_{0}
\end{aligned}
$$

砂地盤で法，地表付近のせん断剛性が小さく，図14や図17に示し たように回転鱼が小さい段階から地盤に沈办込多ながら回転応答

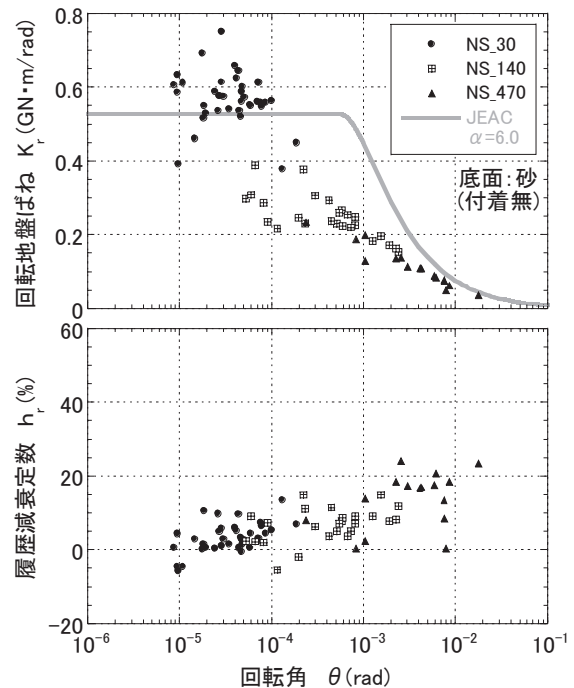

(a) 支持地盤：砂 (付着無)

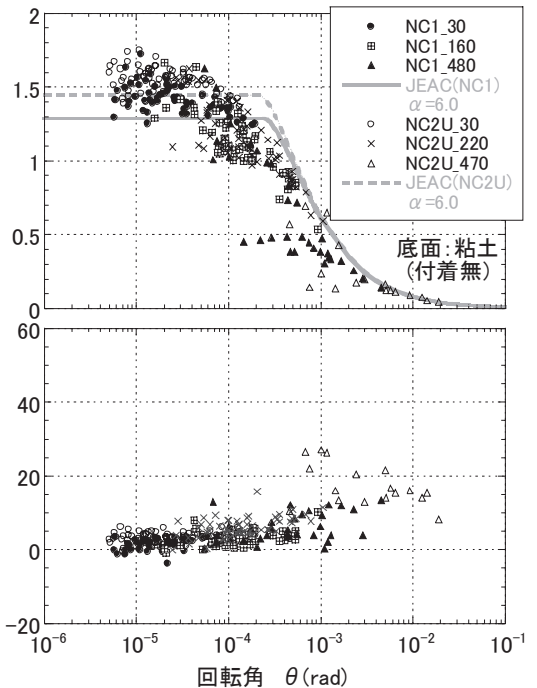

(b) 支持地盤 : 粘土 (付着無)

20回転地盤淮放，履歴減衰定数乙回転角の関係

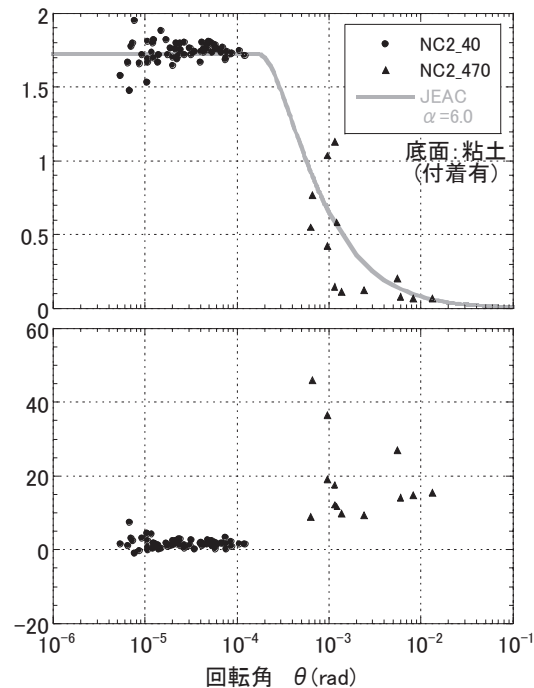

(c) 支持地盤：粘土 (付着有)

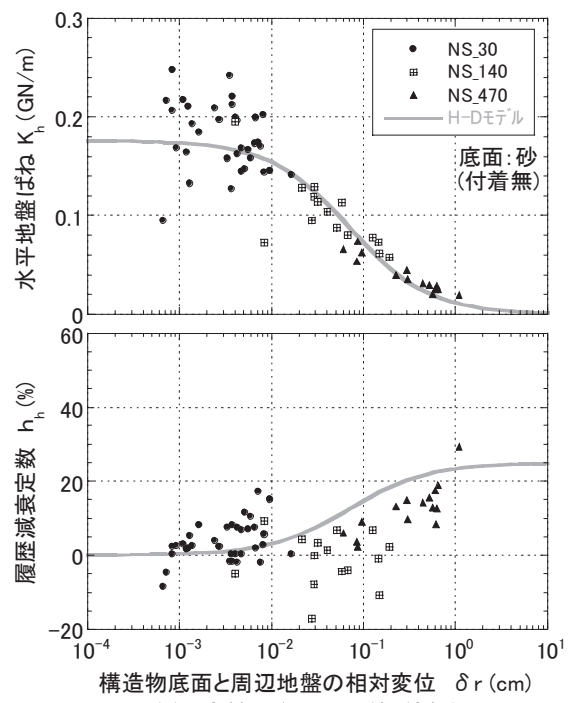

(a) 支持地盤：砂（付着無）

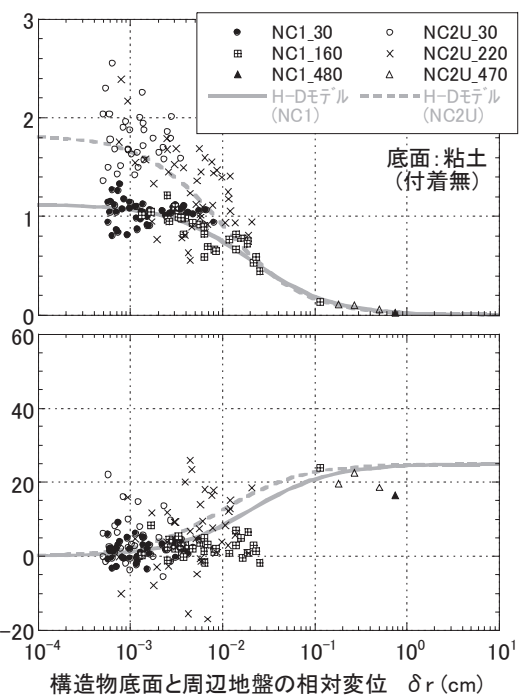

(b) 支持地盤 : 粘土 (付着無)

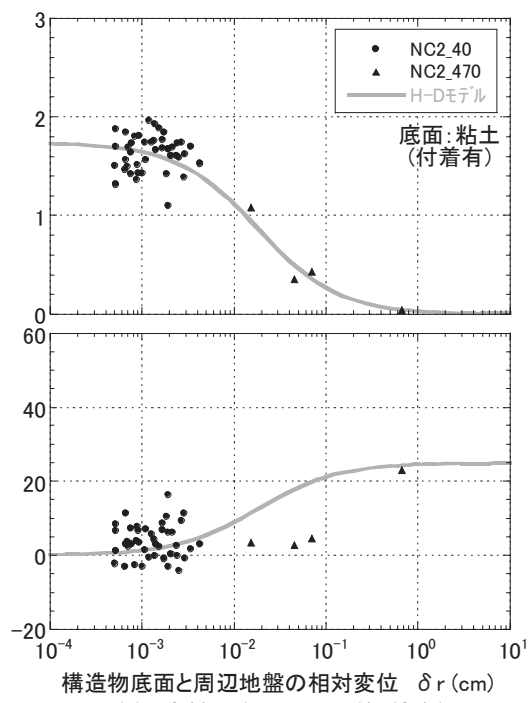

(c) 支持地盤：粘土 (付着有)

図21 水平地盤壮叔, 履歴減衰定数と相対変位 (構造物底面一周辺地盤地表) の関係 
しているため，回転地盤ば称も回転角が小さい段階から低下し， JEACの評洒式よりも剛性低下がかなり早い結果になっている。この 剛性低下に依存して履歴減衰定数が増加している。一方, 粘土地盤 で付着が有る場合には，付着が切れるまでは回転地盤ばねが一定值 を示し, 履歴減衰定数もほぼ零となり, 弹性挙動を示していること が分かる。しかし，付着が切れた後は急激に地盤ば称安減じ，同時に 履歴減衰定数が急激に上昇寸るデー夕が認められる。また, 粘土地 盤で付着が無い場合には，回転角が $5 \times 10^{-5}$ 程度までは回転地盤ばね はほぼ一定值を示し，履歴減衰定数もほぼ零上なっているが，付着 が切れる回転角よりやや小さな回転角から回転地盤ば叔の低下傾 向が認められる。その要因として, 付着の無いケースで法明確な浮 き上がりが生じる直前から部分的な浮き上がりや滑りが生じたこ とが考えられるものの, 実験結果から判断することは難しい。

NC2シリーズには中加振の結果が無いため, 図20(c)の付着が切れ る付近のデータがなく, 明確な傾向が読み取れない部分もあるが, 付着の有無によって浮き上がる直前であっても回転地盤ば敉特性 に差があるものとの推察される。しかし，その要因に関しては実験 結果から判断することは難しく, 今後の課題としたい。

\section{2 底面水平地盤ばね}

図 7 や図 16 亿示した構造物の底面せん断力上相対変位 (構造物底 面一周辺地盤地表) の関係から, 図 19 上同じ定義に従って水平地盤 ばね $\mathrm{K}_{\mathrm{h}}$ 上履歴減衰定数 $\mathrm{h}_{\mathrm{h}}$ 算出し, 支持地盤が砂の場合, 粘土で底 面付着が無い場合上有る場合に分けて図 21 に示寸。なお， $\delta_{\mathrm{r}}$ が $5 \times$ $10^{-4} \mathrm{~cm}$ 以下のデータは除いた。図中には, 土のせん断応力とせん断ひ ずみの非線形特性に用いら就る, 下式に示寸H D モデルで近似 ${ }^{32)} し$ た結果孛併記した。

$$
\begin{aligned}
& \mathrm{K}_{\mathrm{h}}=\mathrm{K}_{\mathrm{ho}}\left\{\frac{1}{1+\delta_{\mathrm{r}} / \delta_{\mathrm{r}, 0.5}}\right\} \\
& \mathrm{h}_{\mathrm{h}}=\mathrm{h}_{\max }\left\{1-\frac{\mathrm{K}_{\mathrm{h}}}{\mathrm{K}_{\mathrm{h} 0}}\right\}
\end{aligned}
$$

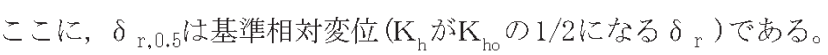
図 7 で求めた $\mathrm{K}_{\mathrm{ho}}$ は非線形性が生じて僅かではあるがループを描い ている結果から求めたものなので, その1.1倍を初期值と仮定し, h max $25 \%$ と仮定してHDモデルで近似した。ばらつきがかなりあるが 水平地盤ば敉は相詨変位の増加に従って低下し, 履歴減衰定数が上 昇寸るといら一般的な非線形特性を示している。また,この非線形 特性は概ね併記したHDモデルで定性的には表現可能と判断される が、ばらつきが大きいため, 付着や接地率の影響・解析的な検討を含 めさらに検討が必要上考えられる。

\section{6. 浮き上がりに伴う誘発上下動と接地率}

構造物の浮き上がりに伴って発生する誘発上下動の最大值 (構造 物鉛直最大加速度) 上, 構造物頂部水平最大加速度, 最大回転角の関
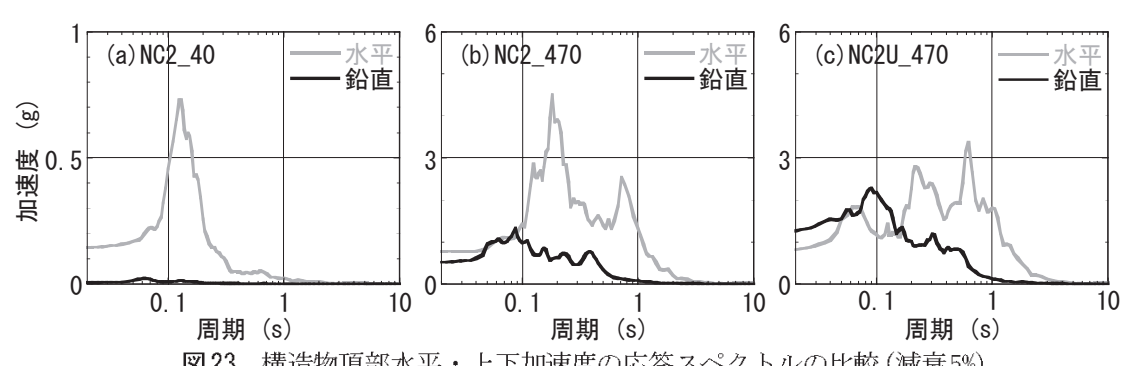

図23 構造物頂部水平・上下加速度の心答スペクトルの比較 (減衰 $5 \%$ )
倸を図 22 に示寸。浮き上がりに誘発されて生じる構造物鉛直最大加 速度は, 構造物頂部の水平最大加速度の増加に伴って急激に増加 し，水平加速度よりも大きくなる場合がある。また，砂地盤上粘土地 盤の差は明確では無い。一方, 構造物最大回転角上の関倸では, 砂地 盤のほうがやや小さい傾向が認められる。

NC2_40,NC2_470, NC2U_470の構造物頂部水平加速度 (SAHO1) 上鈶 直加速度 (\{SAV01+SAV02\}/2) の加速度応答スペクトルを比較して図 23に示寸。底面付着が有るNC2_40では上下動梳小さが，途中から 底面付着が切れるNC2_470では上下動が増加し, ピーク周期は水平 動の1/2(倍調波)になっている。また, 底面付着が無いNC2U_470では さらに上下動が増えているが，ほぼ $1 / 2$ 周期の関倸が維持されてい る。この倍調波の上下動は, 図15に示したように浮き上がりによる 重心移動上再接地時の衝撃による誘発上下動上判断される。

浮き上がりに伴う構造物最小接地率 $\eta$ 上, 最大回転角 $\theta_{\text {max }}$ を浮き 上がり発生時の回転角 $\theta_{0}$ で基淮化した最大基淮化回転角 $\theta_{\text {max }} / \theta_{c}$ の関係を図24に示す。図中には, (4)式に示寸JEACの評価式 $(\alpha=$ 6.0,4.7 ${ }^{18)}$ 学併記している。

実験結果の接地率は $\alpha=6.0$ のライン上かやや大きなところにプ ロットされ，JEACの評価式は最小接地率をやや安全側に評価（接地

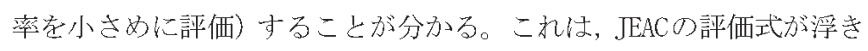
上がりの幾何学的非線形のみ堂扱い，地盤の非線形老考慮していな いためと判断される。また, 図24の関倸は構造物の最大基淮化回転 角から最小接地率を推定可能であることを示している。ただし，付 着が有効に効いている場合は，さらに大きな回転角まで接地率 1.0 の状態が続くと推測されるが, 実験結果が無いため本論で活評価で きていない。

\section{7.まとめ}

砂地盤及び粘土地盤上に設置した剛体構造物模型の浮き上がり に関寸る遠心模型による振動台実験を行い，以下の知見を得た。 1）平均せ九断波速度が注汴同じ砂地盤上粘土地盤に支持された剛
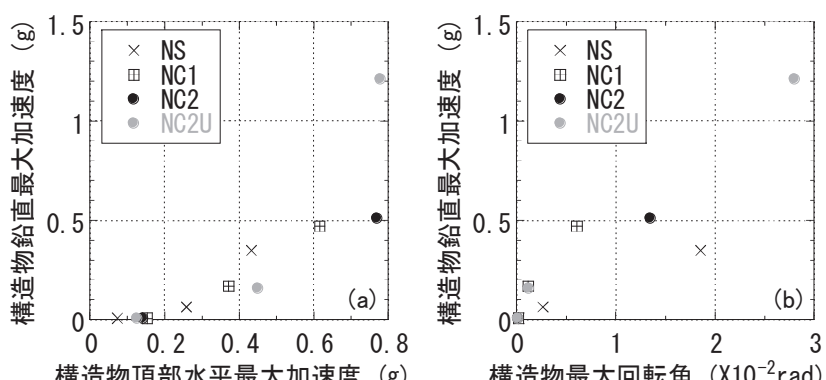

図22 構造物鉛直加速度と水平加速度・回転角の最大值の関係

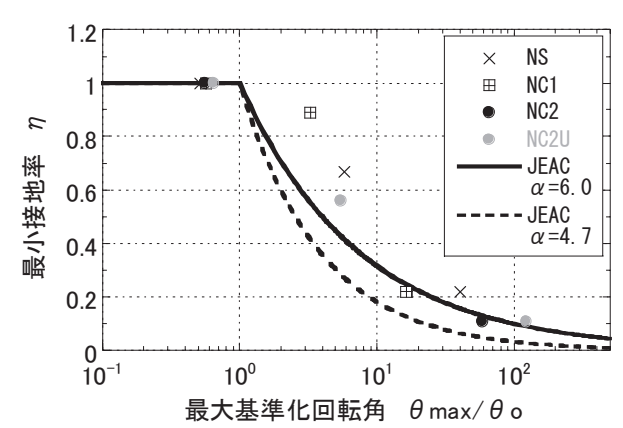

図24 最小接地率々最大基淮化回転角の関保 
体構造物の 1 次ピーク振動数は, 表層付近のせん断波速度が小さ くなる砂地盤の方が約 $1 / 2$ 上明らかに低い。

2）構造物の浮き上がりに伴って構造物頂部の水平加速度は長周期 化すると共に頭打ちとなり，同時に鉛直加速度が増大し，場合に よっては水平加速度学超える鉛直加速度がスパイク状に発生寸 る。地表付近の地盤剛性が砂地盤に比でてより大きな粘土地盤 で浮き上がり後の再接地の際の衝撃が大きく, 構造物鉛直加 速度は上り大きくなる。

3）構造物底面に付着がある場合には無い場合に比心゙て明らかに浮 き上がりが生じ難くなるが，付着が切れる上急激に浮き上がり が生じそれれまでと全く異なった忑答を示す。

4）構造物底面に付着がある場合には限界転倒モーメントを超える 転倒モーメントが発生するが，付着が無い場合は転倒モーメン トが降伏して限界転倒モーメントを概称超えない。

5）構造物底面に付着が無い場合には構造物底面土圧は引張側でほ ぼ零上なるが，付着が有る場合には引㲀側土圧が生じる。この引 張側土圧の影響で構造物の回転角が減少し, 転倒モ一メントが 増大し，鉛直加速度功減少する。

6) 回転地盤ば称は，構造物底面付着の有無に上り浮き上がりが生 じる前から特性がやや異なり，付着無では浮き上がりが生じる 直前から回転地盤ば称の低下が生じるが，付着有ではほぼ一定 值上なり，付着が切れる上急激に低下寸る特性を示す。

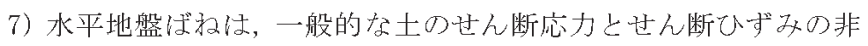
線形特性上同様に，H-Dモデルで定性的には表現可能である。

8）構造物の基淮化回転角から接地率学推定可能である。また，JEAC の評価式は浮き上がりの幾何学的非線形のみ学扱い，地盤の非 線形を考慮していないため, 砂及び粘土を支持地盤に用いた本 実験結果に対してはやや小さわの接地率孛与える。

なおろ，本論文では埋め込み(根入れ)のないモデルの実験結果を報 告した。今後, 埋め込み効果に関寸る実駼結果も別途報告予定であ る。また, 本論の実験は実際の原子力施設上は支持地盤の特性や構 造物の高さ幅比が異なるため,このまま適用できる訳ではない。こ 孔らの違いを明確にし, 本実験で得られた知見学原子力施設に役立 てるため，今後解析的な検討結果も別途報告予定である。

\section{参考文献}

1）武藤清, 小林俊夫 : 水平上下同時入力に対する原子力発電所の非線形ロッ キング地震応答解析, 日本建築学会論文報告集, 第276号, pp.69-77, 1979.2

2）土伎憲三, 佐藤忠信, 三浦房紀 : 強震時に执ける地盤と構造物の間の剥離 已滑動，土木学会論文報告集，第302号，pp. 31-41，1980.10

3）厚美光造, 氏家浩司, 江守克彦, 清水弘道, 小田島政廣, 兼近稳: 建屋と地 盤間の非線形性を考慮した接地率について, その 1 てその 4 , 日本建築学 会大会学術講演梗概集, 構造系, pp. 1421-1428, 1981.9 /同, その5〜その 7, 日本貄築学会大会学術講演梗概集, 構造系, pp.979 984, 1982.10

4）矢野明義, 佐藤仁人, 原昭夫, 内藤幸雄 : 弹性地盤上の㓮体建屋模型の浮 き上り振動実験とその解析 その 1 てその 4 , 日本建築学会大会学術講演 梗概集, 構造系, pp. 755-762, 1983.9

5）山田正明，河村壮一：正弦波多軸入力に上る剖体基礎の浮上り性状に関す 万研究, 日本建築学会論文報告集, 第 340 号, pp. 32-39, 1984. 6

6）高橋郁夫, 市川隆之，林康裕：基礎浮き上がり地震応答に関する研究, 滑動 及び水平二方向入力の影響, 日本建築学会大会学術講演梗概集, 構造系, pp. 2287-2288, 1984.10

7) 上田憲司, 小林正則, 寺田自助, 河村壮一, 山田正明 : 建屋基礎の地震時安 定性評価汇関する研究, その 1 亿の 3 , 日本建築学会大会学術講演梗概 集, 構造系, pp. 2313-2318, 1984.10/同, その 4, 日本建築学会大会学術 講演梗概集, B, pp. 797-798, 1985.10／同，その 5 その 6, 日本建築学会 大会学術講演梗概集, B, pp. 1029-1032，1986.8／同，その 7 その 8, 日
本建築学会大会学術講演梗概集, B, pp. 143-146, 1987.10/同, その9, 日 本建築学会大会学術講演梗概集, B, pp. 1167-1168, 1988.10

8）矢野明義, 江頭信重, 原昭夫, 清田芳治, 内藤幸雄, 堀越清視, 藤本信夫, 兼 近稳：建屋浮き上りに関する静的・動的実験と解析，その 1 てその 3 ，日 本建築学会大会学術講演梗概集, B, pp. 165-170, 1985. 10

9）半谷裕彦，秋野金次：原子炉建屋の基礎浮上りに関する模型試験，その 1 حその 6 , 日本建築学会大会学術講演梗概集, B, pp.971-982, 1986.8

10）下村幸男，田治見宏：正弦加力を受ける基礎の浮上りと地下冕散減衰の関 倸について一半無限弾性地盤上の基礎の浮き上りを伴う動的举動に関す る研究 その 1 -, 日本建築学会構造系論文報告集, 第369号, pp. 87-101, 1986. 11

11）半谷裕彦，秋野金次，尾形隆永：原子炉建屋の基礎浮上りに関する現地試 験, その 1 てその6, 日本建築学会大会学術講演梗概集, B, pp. 219230 , 1987. 10

12）半谷裕彦，秋野金次，尾形隆永：原子炉建屋の基整浮上りに関する模型試 験・総合評価, その $1 \sim 2 の 7$, 日本建築学会大会学術講演梗概集, B, pp. 1153-1166, 1988.10

13）矢野明義, 内藤幸雄, 堀越清視 : 非線形連結要素FEMデルによる基礎浮き 上がり動的解析, 振動台実験のシミュレーションによる精度検討, 日本建 築学会構造系論文報告集，第427号, pp. 87-98, 1991.9

14）大宫幸男, 石崎萬平, 萩原哲也, 栗本修, 田中英朗：基礎浮き上がり在考慮 した原子炉建屋の非線形応答解析, その 1 一その 3 , 日本建築学会大会学 術講演梗概集, B, pp. 1669-1674, 1994.9

15）田中英朗，前田郁生，森山健一，渡辺修二：基礎浮き上がり非線形特性の 合理的評価法に関する検討, その $1 \sim そ の 4$, 日本建築学会大会学術講演 梗概集，B，pp. 1675-1682，1994.9

16）伊東賢伸, 秋田昇道, 奥谷哲也, 栗本修, 白浜健二, 澤饭明広：3次元FEM を用いを建屋一地艋の基礎浮き上がり評価法の高度化に関する研究，その 1 〜その 4, 日本建築学会大会学術講演梗概集, B 2, pp. 625 632, 2004.8

17) Nakamura, N., Ino, S., Kurimoto, O. and Miake, M. :An Estimation Method for Basemat Uplift Behavior of NPP Buildings, Transactions of the 18th International Conference on Structural Mechanics in Reactor Technology, K04/8, pp.3105-3115, 2005.8

18）石川智美, 奥谷哲也, 川里健, 藤森健史, 秋元理仁, 今塚善勝 : 大型遠心模 型に上る基整浮上りに関する研究，その1〜その 2 ，日本建築学会大会学 術講演梗概集，B-2，pp.127-130，2007.8／同，その 3〜その 5, 日本建築 学会大会学術講演梗概集, B-2, pp. 329-334, 2009.8

19）原子力規格委員会：原子力発電所而震設計技術規程 JEAC4601-2008, 社団 法人日本電気協会, p998, 2009. 12

20）羽矢洋, 西村昭彦: 大地震力を考慮した直接基礎の設計法の提案, 土木学 会論文集，NN. 595/VI -39，pp. 127-140，1998.6

21）和田章, 山田哲, 小野泰寛, 小林勝已, 佐及木康人：弾性地盤上の建築構造 物の地震時浮き上がり現象に関する基礎実験，日本建築学会構造系論文 集，第595号，pp. 57-64，2005.9

22) Tamura, S., Adachi, K. and Tokimatsu, K. : Centrifuge tests of impulsive vertical acceleration generated by foundation uplift during strong shaking, Soils and Foundations, Vol.51, No.3, pp.411-422, 2011.6

23）吉川清峰, 荒川利治, 洪忠喜 : 構造物の地震時浮き上がりに関する実験研 究, 日本建築学会大会学術講演梗概集, B, pp. 557-558, 1992. 8

24）野口和也, 石原直, 小豆烟達哉, 井上波彦, 森田高市：浮き上がりが生じる 多層貄築物の地震応答に関する模型振動台実験, その 1 てその 2 , 日本建 築学会大会学術講演梗概集，B-2, pp. 483-486, 2006.9

25）林康裕：直接基礎構造物の基礎浮上りによる地震被害低減效果，日本建築 学会構造系論文集，第 485 号, pp. 5362，1996.7

26）木村秀樹, 荘大作, 岩下敬三, 春日康博：建物の浮き上がり許容に上る制 振構造の開発，その1〜その6, 日本建築学会大会学術講演梗概集，B-2, pp. $549-560, \quad 2001.9$

27) Drnevich, V. P. and Richart, F. E. : Dynamic prestraining of dry sand, Journal of the Soil Mechanics and Foundation Division, ASCE, Vol.96, No.SM2, pp.453-469, 1970.2

28）(財)震㷋予防協会：東京電力株式会社柏崎刈羽原子力発電所に括ける2007 年新潟県中越沖地震など時刻歴データ, 東京電力株式会社, 2008

29）鈴木康嗣, 安達直人：直接基礎底面の祗りが構造物の地震時応答に与える 影響, 鹿岛技術研究所年報, 第58号, pp. 1-6, 2010.9

30）社団法人地盤工学会：地盤材料試験の力法上解説一二分冊の一, 2009.11

31）鈴木康嗣, 三浦賢治, 清田芳治, 菅原良次, 松本尚志 : 地震応答低減地業の 開発，その 3 地震店答低減効果に関する㬰験的検討, 日本建築学会構造 系論文集，第493号，pp.65-72，1997.3

32) Hardin, B. O. and Drnevich V. F. : Shear Modulus and Damping in Soils: Design Equations and Curves, Jounal of the Soil Mechanics and Foundation Division, Proc. of ASCE, Vol.98, No.SM7, pp.667-692, 1972.7

（2013年 1 月 9 日原稿受理，2013年 6 月21日採用決定） 